\title{
Pathological investigations of Vibrio vulnificus infection in Genetically Improved Farmed Tilapia (Oreochromis niloticus L.) cultured at a floating cage farm of India
}

\author{
Sumithra T.G. ${ }^{a}$, Reshma K.J. ${ }^{\mathrm{a}, *, 1}$, Anusree V.N. ${ }^{\mathrm{a}}$, Sayooj P. ${ }^{\mathrm{a}}$, Sharma S.R.K. ${ }^{\mathrm{a}}$, Suja G. ${ }^{\mathrm{a}}$, \\ Amala P.V. ${ }^{a}$, Joseph S. ${ }^{b}$, Sanil N.K. ${ }^{\mathrm{a}}$ \\ ${ }^{a}$ Marine Biotechnology Division, ICAR-Central Marine Fisheries Research Institute, Post Box No. 1603, Ernakulam North P.O., Kochi 682 018, India \\ ${ }^{\mathrm{b}}$ Mariculture Division; ICAR-Central Marine Fisheries Research Institute, Post Box No. 1603, Ernakulam North P.O., Kochi 682 018, India
}

\section{A R T I C L E I N F O}

\section{Keywords:}

Vibrio vulnificus

vvhA gene

pilF polymorphism

GIFT

Cage farm

\begin{abstract}
A B S T R A C T
An outbreak of skin ulcers with morbidity and mortality rate of $80 \%$ and $20 \%$ respectively, among Genetically Improved Farmed Tilapia (GIFT) sub-adults reared in a brackish water floating cage farm of Kochi, Kerala, India was reported. Bacterial isolation attempts from various internal organs (blood, kidney, liver, spleen and brain) of different diseased fish indicated a common bacterial etiology. Organisms were identified as Vibrio vulnificus based on conventional microbiological methods followed by molecular confirmation. Additionally, $V$. vulnificus marker specific for fish virulence was present in the isolates. Fish pathogenicity was confirmed by challenge tests. $\mathrm{LD}_{50}$ was calculated as $2.1 \times 10^{5.13} \mathrm{CFU} /$ fish and $2.1 \times 10^{6.12} \mathrm{CFU} / \mathrm{mL}$ in injection and immersion route respectively. pilF polymorphism-based PCR and $v v h A$ gene sequence indicated potential danger for humans. The strain was positive for siderophore, hemolysin, capsule, polar and lateral flagella. The strain could multiply rapidly in healthy fish serum. All these results indicated that the isolate could act as a primary pathogen for tilapia fish. Interestingly, serum survival ratio of the pathogen was significantly larger at higher temperatures $(p \leq .05)$; which may explain the increase in infective capacity of $V$. vulnificus at higher temperature. Multiple antibiotic resistance index of the strain was $\leq 0.2$. In conclusion, the paper provides detailed descriptions of clinical signs, microscopic and macroscopic lesions of a natural disease outbreak among tilapia raised in brackish water cage farms of India. The concurrent attempts to identify and characterize the etiology fetches the basis for future development of effective control and preventive measures against $V$. vulnificus, the most infectious and lethal of all zoonotic vibrios.
\end{abstract}

\section{Introduction}

Aquaculture is the fastest growing food production sector in the world (FAO, 2018). As aquaculture through cage farming offers 70 times more production than ponds, the same is getting popularized globally (Rutaisire et al., 2009; Mugamire et al., 2013). Cage culture of fish in marine or brackish water environments holds a considerable potential for enhancing aquaculture production in arid and tropical coastal areas where seawater is abundant, sparing freshwater resources for agriculture and other human activities (McGeachin et al., 1987; Watanabe et al., 1989). Genetically Improved Farmed Tilapia (GIFT) (Oreochromis niloticus L.) are excellent candidates for aquaculture in offshore cage farms due to their ability to withstand wide range of salinity (El-Sayed, 2006). Accordingly, The ICAR-Central Marine Fisheries Research Institute (ICAR-CMFRI), Kochi, India, has initiated a number of research and development programs on farming of this fish strain in brackish water cages as a viable farming option during southwest monsoon season in Kerala (Imelda et al., 2014). Nevertheless, limited data are available on their diseases in such cages.

Modern techniques of intensive and super-intensive farming systems have significantly increased the incidences of infectious diseases in commercial aquaculture systems (Mukherjee, 2002). Among infectious agents, bacterial diseases are reported to be the largest single cause of economic losses in aquaculture (Zhou et al., 2009; Stentiford et al., 2012). Vibriosis is one of the major devastating diseases of fish causing high mortalities and severe economic losses to cage aquaculture

\footnotetext{
* Corresponding author.

E-mail addresses: reshma.kj@icar.gov.in, sumithra.g@icar.gov.in (K.J. Reshma).

${ }^{1}$ Present address: Scientist, Marine Biotechnology Division, ICAR- Central Marine Fisheries Research Institute, Post Box No. 1603, Ernakulam North P.O., Kochi682018.
} 
systems of marine or brackish water environments (Samuelsson et al., 2006; Sarjito et al., 2009; Chatterjee and Haldar, 2012). However, only a few Vibrio species such as $V$. anguillarum, $V$. alginolyticus, $V$. vulnificus, $V$. ordalii and $V$. salmonicida are reported to be economically important in aquaculture (Sandlund et al., 2010). Among these, V. vulnificus is noteworthy since it causes severe disease in humans, fish, and shrimps (Chen et al., 2006). This bacterium is considered the most infectious and lethal of all human pathogenic vibrios and has become a serious concern (Levin, 2005).

Fish-pathogenic V. vulnificus was initially isolated from Japanese eel in 1975 (Muroga et al., 1976). Later, epizootics of $V$. vulnificus infection were described among tilapia (Sarotherodon niloticus) of saltwater pens in Japan (Sakata and Hattori, 1988) at $18-20^{\circ} \mathrm{C}$. Fouz et al. (2002) showed that tilapia (O. niloticus) were susceptible to experimental challenge with eel-pathogenic V. vulnificus. Fouz and Amaro (2003) reported two outbreaks of $V$. vulnificus among freshwater eel farms of Spain. Later, Shoemaker et al. (2011) characterized V. vulnificus isolate from diseased hybrid tilapia (O. niloticus $\times O$. aureus) of USA. A detailed description of a natural infection caused by $V$. vulnificus in tilapia fish cultured at Indian brackish water cage farm has been presented in this paper. This forms the first report of a natural and experimental infection caused by $V$. vulnificus in fish cultured in brackish water cage farm of India. Further, microbiological, molecular and virulence characteristics of the pathogen was comprehensively documented.

\section{Materials and methods}

\subsection{Natural outbreak}

Two thousand tilapia fish and one thousand Pearl spots (Etroplus suratensis) were maintained in square shaped high density polyethylene floating cage $\left(6 \mathrm{~m} \times 6 \mathrm{~m} \times 1 \frac{1}{2} \mathrm{~m}\right)$ moored in a brackish water ecosystem off Kochi, Kerala, India (latitude: $9^{\circ} 85^{\prime} \mathrm{N}$; longitude $76^{\circ} 38^{\prime} \mathrm{E}$ ) (Fig. 1). Similar types of two cages were moored in the same location in which mangrove red snapper (Lutjanus argentimaculatus) were stocked. Fish were fed with commercial dry pellet (Growel) three times daily. A cumulative mortality of $20 \%$ was recorded within one-week period after 9 months initial stocking with hemorrhagic lesions and ulcers on the skin among tilapia fish (598.44 $\pm 56.05 \mathrm{~g}$ weight) during January 2018. The affected fish were reported to show the clinical signs of surfacing, anorexia, corneal opacity, erratic swimming behavior, lateral recumbency and finally acute mortality. There was no mortality or abnormal signs in other two species of fish. After recording temperature, $\mathrm{pH}$ and salinity of the resident water, moribund fish showing gross clinical signs were transported in live condition to Fish Microbiology laboratory, Marine Biotechnology Division, ICAR-CMFRI for further investigations. Sampling was done in accordance with USFWS/AFS-FHS (2004).

\subsection{Necropsy examination}

After recording gross external and internal lesions, wet impression smears were taken from skin and gill to know the presence of any parasites. Blood, liver, kidney and spleen were aseptically excised and homogenized in sterile normal saline solution. Blood and tissue homogenates were directly streaked on Zobell Marine Agar (ZMA; Himedia), Brain Heart Infusion Agar (BHIA; Himedia), 1/10th strength nutrient agar (NA; Himedia) and Thiosulphate Citrate Bile Salt Sucrose agar (TCBS; Himedia). Inoculated plates were kept for incubation at $28^{\circ} \mathrm{C}$, and the colonies formed were picked and streaked onto ZMA plate and incubated further. The isolates were stored as ZMA slants at $4{ }^{\circ} \mathrm{C}$ and as glycerol stocks at $-80^{\circ} \mathrm{C}$. Morphological and major biochemical characters were investigated based on Bergey's Manual of Systematic Bacteriology (Bergey et al., 2012) for the preliminary identification of pathogen. Infected fish tissue samples were also screened for the presence of 2 viral pathogens of tilapia namely, betanodavirus and Tilapia lake virus by PCR (Bigarre et al., 2009; Eyngor et al., 2014). As the preliminary identification methods tentatively indicated the infective bacteria as $V$. vulnificus, molecular confirmation of the isolates were done by PCR amplification using species specific primers (Kaysner and DePaola, 2004) with minor modifications. The cycling conditions were $94^{\circ} \mathrm{C}$ for 5 min, 30 cycles of $94^{\circ} \mathrm{C}$ for $30 \mathrm{~s}, 55^{\circ} \mathrm{C}$ for $30 \mathrm{~s}$ and $72^{\circ} \mathrm{C}$ for $1 \mathrm{~min}$ followed by $72^{\circ} \mathrm{C}$ for $10 \mathrm{~min}$. The amplification products were verified by the presence of the desired band (519 bp) on 1\% agarose gel. Further, PCR was performed using primers targeting $V$. vulnificus virulence markers specific for fish virulent strains (Sanjuan and Amaro, 2007) with minor modifications. The cycling conditions were $94^{\circ} \mathrm{C}$ for $5 \mathrm{~min}, 35$ cycles of $94^{\circ} \mathrm{C}$ for $30 \mathrm{~s}, 60^{\circ} \mathrm{C}$ for $1 \mathrm{~min}$ and $72{ }^{\circ} \mathrm{C}$ for $1 \mathrm{~min} 30 \mathrm{~s}$ followed by $72^{\circ} \mathrm{C}$ for $10 \mathrm{~min}$. The amplicons were verified by running on $1.5 \%$ agarose gel and sequencing of the representative amplicon. The sequence was then submitted to GenBank database under accession number MK751426.

\subsection{Histopathology}

Representative samples of liver, spleen and gill from diseased fish were fixed in 10\% neutral buffered formalin (NBF) for histopathology. Tissues were processed using routine methods and embedded in paraffin wax. The sections cut $4 \mu \mathrm{M}$ thickness were then stained using haematoxylin and eosin (H\&E) (Sharma et al., 2013).

\subsection{Challenge experiments}

\subsubsection{Experimental fish}

Apparently healthy juvenile fish (O. niloticus) with a mean weight of $15 \mathrm{~g}$ (10 to $20 \mathrm{~g}$ ) were used for the challenge study. Fish were brought from an aquaculture facility and maintained in oval shaped FRP tanks containing $210 \mathrm{~L}$ of de-chlorinated, and continuously aerated water having a salinity of $12 \mathrm{ppt}$ and temperature of $25 \pm 2^{\circ} \mathrm{C}$ for 2 weeks. The fish were fed ad libitum with floating pellet feed and $30 \%$ water exchange was made on daily basis. Ammonia level was checked daily and maintained below optimum. The animals were allowed to acclimatize for 2 weeks; active feeding was noted for fish after the first week. Before beginning each experiment, three fish were randomly necropsied, blood, cranial kidney and spleen were collected for bacteriological examination to rule out the presence of any bacterial infection (Pretto-Giordano et al., 2010). All fish sampled in this study were handled in strict accordance with the guidelines for the care and use of fish in research by De Tolla et al. (1995) and the protocols were approved by ICAR- Central Marine Fisheries Research Institute, Kochi, India. All experiments were performed in triplicates to maintain the consistency of the results. In all the experiments, clinical signs of moribund fish were recorded, and dead fish were subjected to gross pathological and bacteriological examination immediately after death. For bacteriological examination, samples of blood, brain, liver, spleen and kidney were aseptically plated on TCBS agar. The obtained colonies were confirmed biochemically and molecularly as V. vulnificus (Kaysner and DePaola, 2004). Mortalities were considered only if the challenged strain was re-isolated in pure form from challenged fish (Amaro et al., 1992).

\subsubsection{Testing for pathogenicity through experimental infection}

Representative isolate from the infected fish (named as CMFRI/VV02) was inoculated into fresh LB broth with $1 \% \mathrm{NaCl}$ and incubated at $28^{\circ} \mathrm{C}$ with shaking for $18 \mathrm{~h}$, followed by centrifugation (10, $000 \mathrm{rpm}$ for $20 \mathrm{~min}$ at $4^{\circ} \mathrm{C}$ ) and re-suspension in sterilized PBS. During the challenge experiments, the fish were maintained in glass tanks containing $40 \mathrm{~L}$ of filtered water (salinity-12 ppt; temperature $25 \pm 2{ }^{\circ} \mathrm{C}$ ) with continuous aeration. The experimental fish were randomly divided into four groups (two infected groups and two control groups, six fish per tank; each group in triplicates) and used for testing the pathogenicity of the isolate. The first group was injected intramuscularly with $0.1 \mathrm{~mL}$ of 


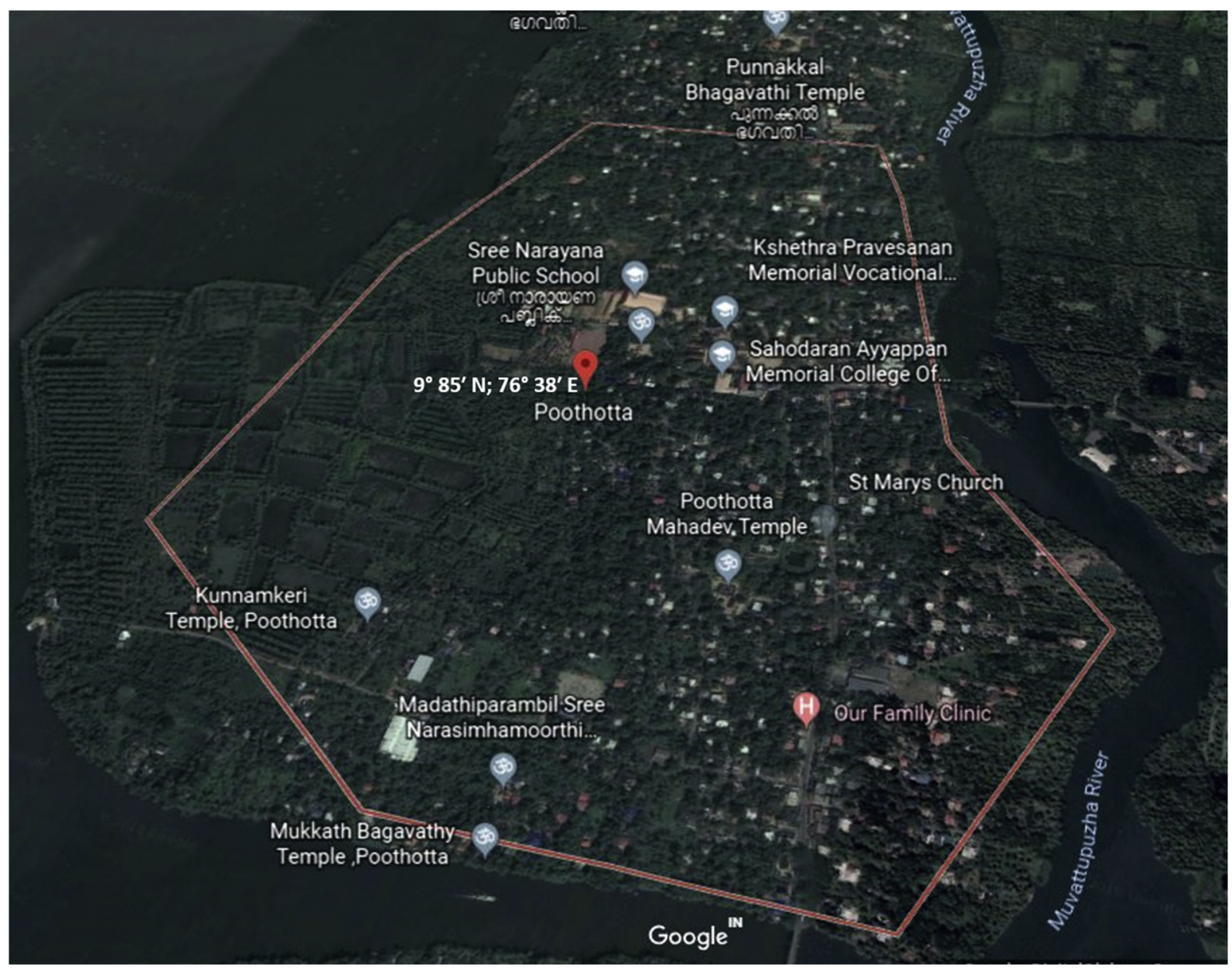

Fig. 1. Sampling location of the present study.

the bacterial suspension containing $10^{10} \mathrm{CFU} / \mathrm{mL}$. The second batch was injected with $0.1 \mathrm{~mL}$ of sterile PBS to form the control group for injection challenge. The third group was maintained in glass aquaria to which the bacterial suspension was loaded to reach a final concentration of $10^{8} \mathrm{CFU} / \mathrm{mL}$. The forth group was maintained as a control for immersion challenge. All the fish were monitored for 14 days.

\subsubsection{Determination of LD50 through injection challenge}

Tenfold serial dilutions of the bacterial suspension (prepared as above) were made in sterile PBS. A dose range of $2.1 \times 10^{1}$ to $2.1 \times 10^{8} \mathrm{CFU} /$ fish was then used to find out the minimum dose required for causing $50 \%$ mortality through injection challenge. Experimental fish were maintained in 14 glass tanks containing $40 \mathrm{~L}$ of filtered water (salinity-12 ppt; temperature $25 \pm 2^{\circ} \mathrm{C}$ ) with continuous aeration. Each tank contained six fish with triplicate tanks for each dose. The fish were injected intramuscularly with $0.1 \mathrm{~mL}$ of the bacterial suspension containing $2.1 \times 10^{2}-2.1 \times 10^{9} \mathrm{CFU} / \mathrm{mL}$. Control fish were injected with $0.1 \mathrm{~mL}$ of sterile PBS. All fish were monitored for 10 days and mortalities recorded. Afterwards, LD50 was calculated as per Reed and Muench (1938).

\subsubsection{Determination of LD50 through immersion challenge}

Tenfold serial dilutions of the bacterial suspension (prepared as above) were prepared in sterile PBS and placed into the water tanks containing $40 \mathrm{~L}$ of filtered water (salinity-12 ppt; temperature $25 \pm 2 \mathrm{C}$ ) with continuous aeration, at final concentrations of $2.1 \times 10^{3}-2.1 \times 10^{9} \mathrm{CFU} / \mathrm{mL}$. Each tank contained six fish with triplicate tanks for each dose. Immersion infection was conducted as per Lavilla-Pitogo et al. (1992). Healthy tilapia juveniles were randomly divided into 8 groups (seven infected groups and one control group, six fish per group, each group in triplicates) and challenged by immersion. Fish were maintained in the various concentrations of bacterial suspensions described above for 14 days. Fish in the control group were placed in filtered water (salinity-12 ppt; temperature $25 \pm 2^{\circ} \mathrm{C}$ ) for 14 days. During the period of immersion, no food was provided, and the water was not renewed to maintain the stable water environment and bacterial concentration. The experimental fish were observed daily, and disease signs and death status were recorded. Afterwards, LD50 was calculated as Reed and Muench (1938).

\subsection{Molecular characterization by $16 S$ rRNA gene sequencing}

Genomic DNA was extracted from the representative isolate by CTAB method (Wilson, 1987) and 16S rRNA gene ( $1500 \mathrm{bp}$ ) was amplified using universal bacterial primers, NP1F 5'GAGTTTGATCCT GGCTCA-3' and NP1R 5'-ACGGCTACCTTGTTACGACTT- 3' (Nair et al., 2012). The amplicons were Sanger sequenced at a custom DNA sequencing facility (Agrigenome, India). The sequence was subjected to homology search using NCBI-BLAST. The overlapping $820 \mathrm{bp}$ fragment of $16 S$ rRNA gene from both sequencing reactions was then aligned using ClustalW and a phylogenetic tree was constructed by neighborjoining method (MEGA version 7 software) using Kimura 2-parameter model (selected based on its lowest BIC score, Bayesian information criterion) (Kumar et al., 2016). The corresponding sequence of $V$. parahaemolyticus was used as an out-group for rooting trees. The confidence in $\mathrm{NJ}$ tree was estimated by 1000 bootstrap replicates. Nucleotide sequence of $16 S$ rRNA gene from CMFRI/VV-02 strain was submitted to GenBank database under accession number MH355960. 


\subsection{Screening for virulence determinants}

The presence of various factors associated with virulence of $V . v u l-$ nificus namely, haemolysin, protease, siderophore, capsule and flagella was checked in the representative isolate (CMFRI/VV-02). For haemolysin detection, strains were streaked on nutrient agar enriched with $5 \%$ bovine blood. Plates were incubated for $24 \mathrm{~h}$ at $37^{\circ} \mathrm{C}$, and checked for the presence of hemolysis halos (Moreno and Landgraf, 1998). Proteolytic activity was detected by spotting bacteria on nutrient agar containing $2 \%$ concentration of skim milk. After incubation at $37^{\circ} \mathrm{C}$ for 24-48 h, formation of a clear halo around the culture spot was checked (Moreno and Landgraf, 1998). To demonstrate the presence of siderophore, the bacteria was spotted onto the surface of Chrome azurol S (CAS) agar and incubated for $24 \mathrm{~h}$ at $37^{\circ} \mathrm{C}$. The formation of yelloworange halo aroud the culture spot was observed (Schwyn and Neilands, 1987). The presence of capsule was tested by India ink staining. The existence of polar and lateral flagella, involved in swimming and swarming movements was also tested. For swimming, the isolate was plated on Brain Heart Infusion Agar (BHI; Himedia) with $2 \%$ sodium chloride and $0.3 \%$ agar and incubated at $37^{\circ} \mathrm{C}$ for $24 \mathrm{~h}$. For swarming, the isolate was inoculated into BHI agar plates with $1 \%$ agar and incubated for $48 \mathrm{~h}$ at $37^{\circ} \mathrm{C}$ (Natividad-Bonifacio et al., 2013).

\subsection{Tolerance to environmental variables}

Ability of the representative isolate (CMFRI/VV-02) to tolerate different environmental variables namely, temperature, $\mathrm{pH}$ and salinity was done by checking the presence or absence of growth at varying temperature $\left(4-50^{\circ} \mathrm{C}\right)$, salinity $(0-10 \%)$ and $\mathrm{pH}(1-14)$ for $24-72 \mathrm{~h}$.

\subsection{Bacterial survival in serum}

Survival of the representative isolate (CMFRI/VV-02) in healthy naïve tilapia serum was measured. Briefly, bacterial cell suspensions in PBS $\left(10^{7} \mathrm{CFU} / \mathrm{mL}\right)$ were incubated in serum samples (pooled from 4 to 6 fish) with duplicates and incubated at $25^{\circ} \mathrm{C}, 28^{\circ} \mathrm{C}$ and $32{ }^{\circ} \mathrm{C}$ for $4 \mathrm{~h}$. Bacterial cell suspension incubated in PBS under different temperature acted as control for each experiments. Afterwards, viable cell counts were found out by drop-plating the serial dilutions on ZMA plates (Fouz et al., 2002).

\section{9. vvhA gene sequence analysis}

Representative amplicon ( $v$ hA gene) obtained during the molecular confirmation step using species specific primers (Kaysner and DePaola, 2004) was purified and sequenced at Agrigenome, India. The sequence was then submitted to GenBank database under accession number MH357338. The overlapping 455 fragment of $v v h A$ gene from both sequencing reactions was then aligned against other $V$. vulnificus strains using CLUSTAL-W and the aligned data set was used for the $v v h A$ group identification and as the input for phylogenetic analysis. In phylogenetic analysis, $v v h A$ gene sequence of strain L-180 (a group 1 strain from human blood) and CDC B3547 (a group 2 strain from human leg ulcer) (Senoh et al., 2005) was also included. The analysis was done by neighbor-joining method (MEGA version 7 software) using Kimura 2parameter model (Kumar et al., 2016) with the confidence in NJ tree estimated by 1000 bootstrap replicates.

\subsection{0. pilF polymorphism-based PCR}

To ascertain public heath significance of the fish pathogen in the present outbreak, a pilF gene based PCR targeting the variable region associated with potential human pathogenicity, was performed using specific primers (Roig et al., 2010) and pfu enzyme. The cycling conditions were $95^{\circ} \mathrm{C}$ for $2 \mathrm{~min}, 35$ cycles of $95^{\circ} \mathrm{C}$ for $20 \mathrm{~s}, 65^{\circ} \mathrm{C}$ for $40 \mathrm{~s}$ and $72{ }^{\circ} \mathrm{C}$ for $2 \mathrm{~min}$ followed by $72^{\circ} \mathrm{C}$ for $5 \mathrm{~min}$. The specific amplifications were verified by the presence of desired band on $1.5 \%$ agarose gel and sequencing.

\subsection{Antibiotic susceptibility test}

In-vitro antibiotic susceptibility of the representative isolate (CMFRI/VV-02) to 23 antibiotics belonging to 9 different classes (HiMedia Laboratories, Mumbai, India) was analyzed using disc diffusion test as recommended by Clinical and Laboratory Standard Institute (CLSI, 2018) antimicrobial susceptibility testing. Inhibition zones were measured and the antimicrobial susceptibility of strain was determined. E. coli ATCC25922 was run in parallel as a reference strain for antibiotic susceptibility test. Established criteria for Vibrio vulnifcus by WHO was used for interpretation as either susceptible, intermediate, or resistant using WHONET (http://www.whonet.org) version 5.6. Multiple antibiotic resistance (MAR) index was calculated using the formula MAR index $=X / Y$, where ' $\mathrm{X}$ ' represents the number of antibiotics to which the isolate showed resistance and ' $\mathrm{Y}$ ' represents the total number of antibiotics to which the isolate was evaluated (Krumperman, 1983).

\subsection{Statistical analysis}

One-way ANOVA followed by post-hoc Tukey's HSD test was used to compare the bacterial survival ratio in naive fish serum at different temperatures. Value of $P<.05$ was set to represent significant difference. Statistical analyses were carried out using SPSS (SPSS Inc. IL, Chicago) Version 16.

\section{Results}

\subsection{Gross observations}

Hydrographic parameters of cage water were as follows: Salinity$12 \mathrm{ppt}$, temperature- $31^{\circ} \mathrm{C}$ and $\mathrm{pH}-7.1$. Many of the diseased fish in stock showed dark discoloration of skin, a characteristic deep ulcer exposing the underlying muscle below dorsal skin (Fig. 2a) and external hemorrhages on fins (Fig. 2b). Eyes revealed corneal opacity (Fig. 2c). Redness or erythematous patches were observed on lower abdomen and lower mandibular region. Blood was pale and watery. Gills were pale. In several fish, abdomen was distended with yellowish transparent gelatinous peritoneal fluid. Internally, the lesions were as follows; generalized fat accumulation in the abdominal cavity, pale liver with congested blood vessels, congested mucosa of stomach, yellowish transparent gelatinous fluid filled intestine, engorged gall bladder, congested and enlarged kidneys and splenomegaly.

\subsection{Screening for parasitic and viral pathogens}

PCR amplification for detection of tilapia lake virus and betanodavirus did not yield any products. Macroscopic and microscopic examination of gill and body surfaces of the diseased fish, did not show any parasites and protozoans.

\subsection{Bacterial isolation and characterization}

From the naturally infected moribund fish less opaque, small to medium sized bacterial colonies and green opaque colonies were isolated on ZMA/BHIA and TCBS agar plates respectively, from blood, liver, kidney and spleen samples. There was no growth in 1/10thstrength nutrient agar. Bacterial isolation attempts from different diseased fish gave morphologically similar isolates, indicating a common bacterial etiology in the stock. Based on conventional microbiological methods and PCR using species specific primers, the infective bacteria were identified as $V$. vulnificus. On PCR amplification of $v v h A$ gene encoding haemolysin, an expected amplicon of $\sim 519 \mathrm{bp}$ was obtained with all the isolates. Further, there was amplification of specific fish 


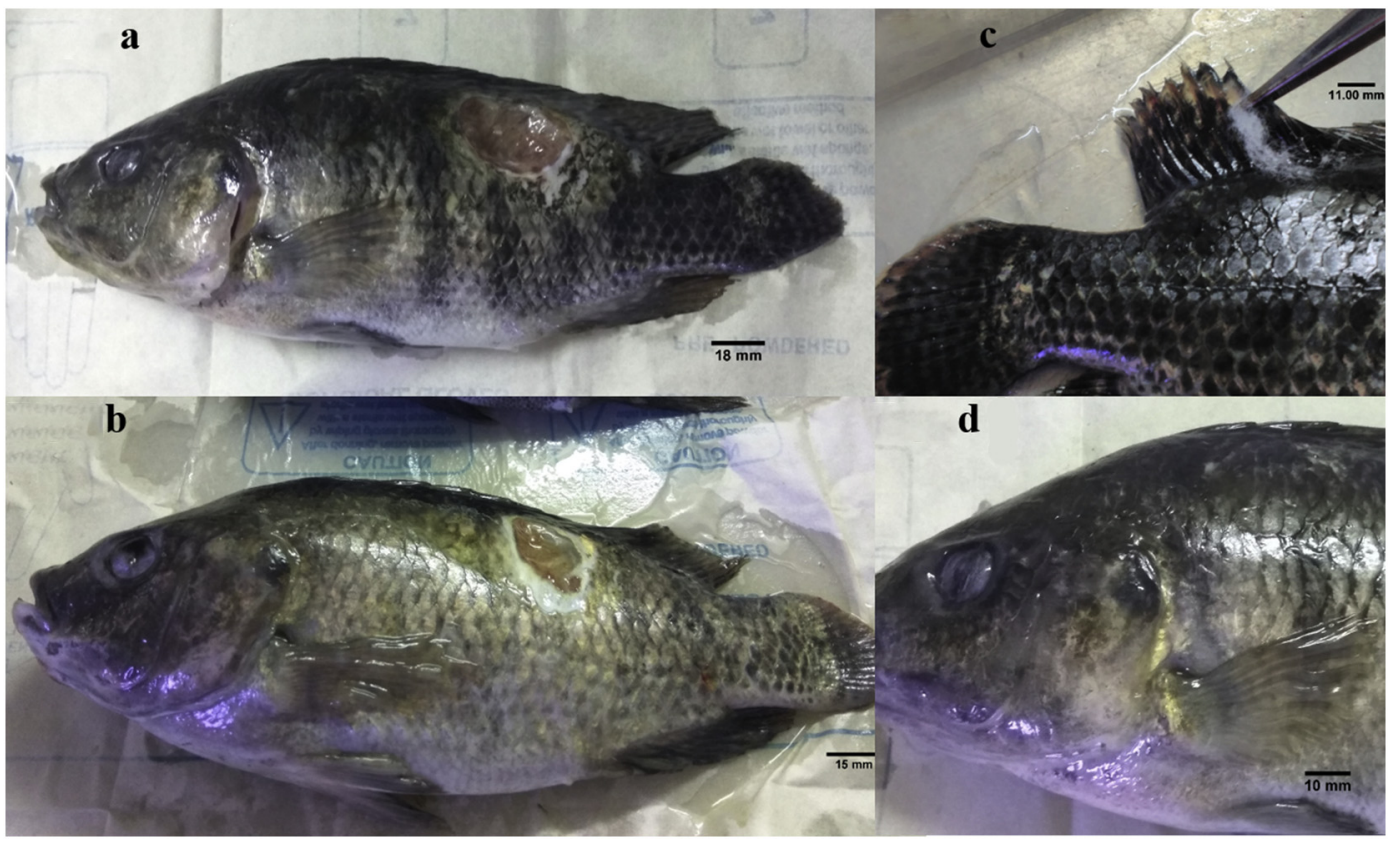

Fig. 2. Macroscopic lesions observed during natural disease outbreak. Fig. 2a Characteristic deep ulcer exposing the underlying muscle below dorsal skin; Fig. 2b: Hemorrhages on fins; Fig. 2c: Corneal opacity.

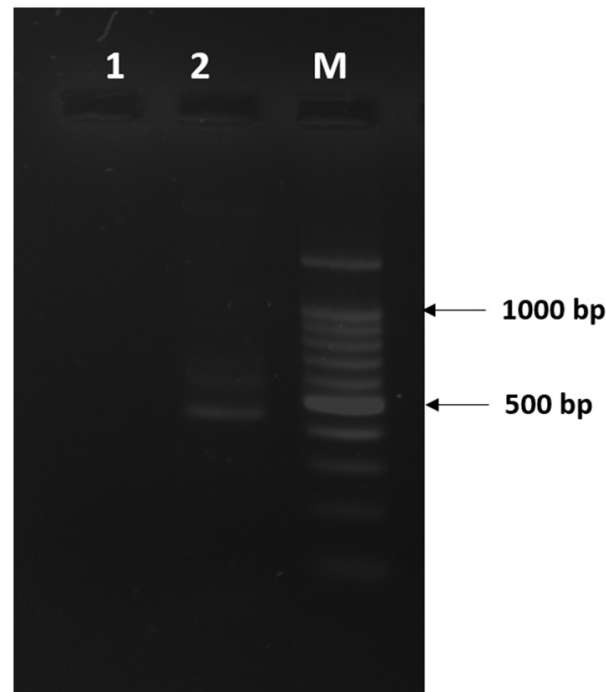

Fig. 3. PCR amplification of $V$. vulnificus virulence marker specific for fish virulent strains.

Lane M: GeneRuler ${ }^{\mathrm{TM}} 1 \mathrm{~kb}$ DNA Ladder, Lane 1: Negative control, Lane 2: Specific amplification product.

virulent sequences by PCR and the specific amplification was confirmed by sequencing of the representative amplicon (GenBank Accession number MK751426) (Fig. 3).

\subsection{Histopathology}

Hemorrhage was the consistent microscopic finding in all the tissues examined. Additionally, hepatic parenchyma revealed fatty changes, vascular engorgement due to active congestion (Fig. 4a), degeneration and necrotic areas among perivascular hepatocytes, and hypertrophic changes in biliary epithelium (Fig. 4b). In a few places, necrotic hepatocytes were replaced by erythrocytes (Fig. 4c). Increased deposits of hemosiderin could be observed throughout splenic parenchyma (Fig. 4d). There were hyperplastic changes in gill with mild to extensive hyperplasia leading to fusion of secondary lamellae.

\subsection{Challenge experiments}

Koch's postulate was confirmed by the experimental infection and re-isolation from the moribund fish (blood, liver, brain, kidney and spleen) through injection and immersion challenge. The mortality was $100 \%$ in both challenge experiments. At the same time, no bacteria could be isolated from control group. All the infected fish died between 24 and $48 \mathrm{~h}$ after injection challenge and within 3-5 days after immersion challenge. Fish infected by both routes showed reduced appetite, surfacing, dark coloration of skin, imbalance, less activity, exophthalmia and ascites. The blood was pale and watery. The gross lesions observed were; ascites (Fig. 5a), petechiae on skin (Fig. 5b), hemorrhages on fins (Fig. 5c, d) and exophthalmia. Internal organs showed generalized hemorrhages, renal fragility, splenomegaly, dark red discoloration of the liver and engorged gall bladder. Gastric and intestinal lumen were filled with yellowish gelatinous fluid. No external or internal parasites and ulcers were observed.

\subsection{Determination of LD50}

$\mathrm{LD}_{50}$ value of $V$. vulnificus was found to be $2.1 \times 10^{5.13} \mathrm{CFU} /$ fish and $2.1 \times 10^{6.12} \mathrm{CFU} / \mathrm{mL}$ in injection and immersion challenge respectively. Cumulative mortality percentage of tilapia juveniles challenged with different doses of $V$. vulnificus within 10 days and 14 days in injection and immersion challenge respectively was represented in Fig. 5. Briefly, the isolated strain infected fish showed clinical signs and mortality from day 2 and day 3 post-challenge in injection and immersion challenge respectively. Cumulative mortality \% at different CFUs of pathogen following immersion and injection challenge were depicted in Fig. 6.

\subsection{Phylogenetic analysis based on $16 S$ rRNA gene sequence}

Using BLAST search on GenBank in which $16 S$ rRNA sequence (MH355960.1) of CMFRI/VV-02 showed 100\% homology to many $V$. vulnificus strains including the type strain (ATCC 27562) (Accession number NR 117906) and the strain 93 U204 isolated from a diseased 


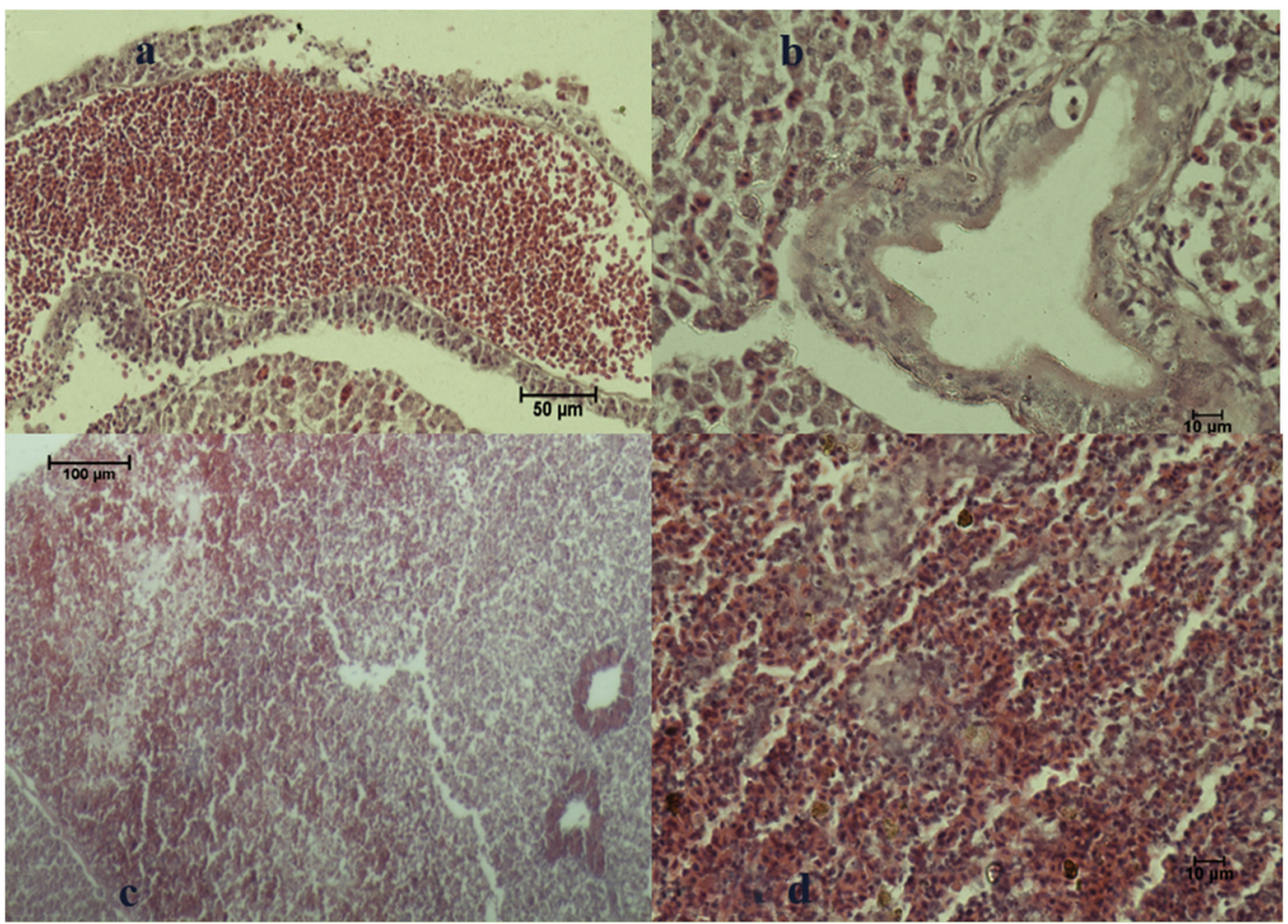

Fig. 4. Histopathology of tilapia infected with $V$. vulnificus in natural disease outbreak. Fig. 4a Vascular engorgement in hepatic parenchyma H\&E Bar $=50 \mu \mathrm{M}$; Fig. 4b: Hypertrophic changes in biliary epithelium H\&E Bar $=10 \mu \mathrm{M}$; Fig. 4c: Replacement of necrotic hepatocytes by erythrocytes H\&E Bar $=100 \mu \mathrm{M}$; Fig. 4d: Increased hemosiderin deposits in splenic parenchyma H\&E Bar $=10 \mu \mathrm{M}$.

Hybrid tilapia in Taiwan (Accession number CP009261.1). The percentage similarity with $16 \mathrm{~S}$ rRNA gene sequence of other closely related Vibrio sp., such as V. diazotrophicus strain NBRC103148 (NR118930.1), $V$. fluvialis strain VL5125 (NR036790.1), V. anguillarum strain NBRC13266 (NR113609.1) and $V$. ordalii strain ATCC33509 (NR044851.1) were 98\%, 98\%, 98\% and 97\% respectively. Comparative phylogenetic tree analysis of CMFRI/VV-02 strain and other Vibrio strains using $16 S$ rRNA sequences was depicted in Fig. 7.

\subsection{Screening of virulence determinants and tolerance to environmental} variables

CMFRI/VV-02 produced $\beta$ hemolysis on blood agar within $48 \mathrm{~h}$. The strain was positive for capsule and siderophore production. It produced swimming and swarming movements. However, it showed no protease activity on skim milk agar. In the tests for tolerance to environmental variables, the isolate could survive in a temperature range of $20-45^{\circ} \mathrm{C}$,

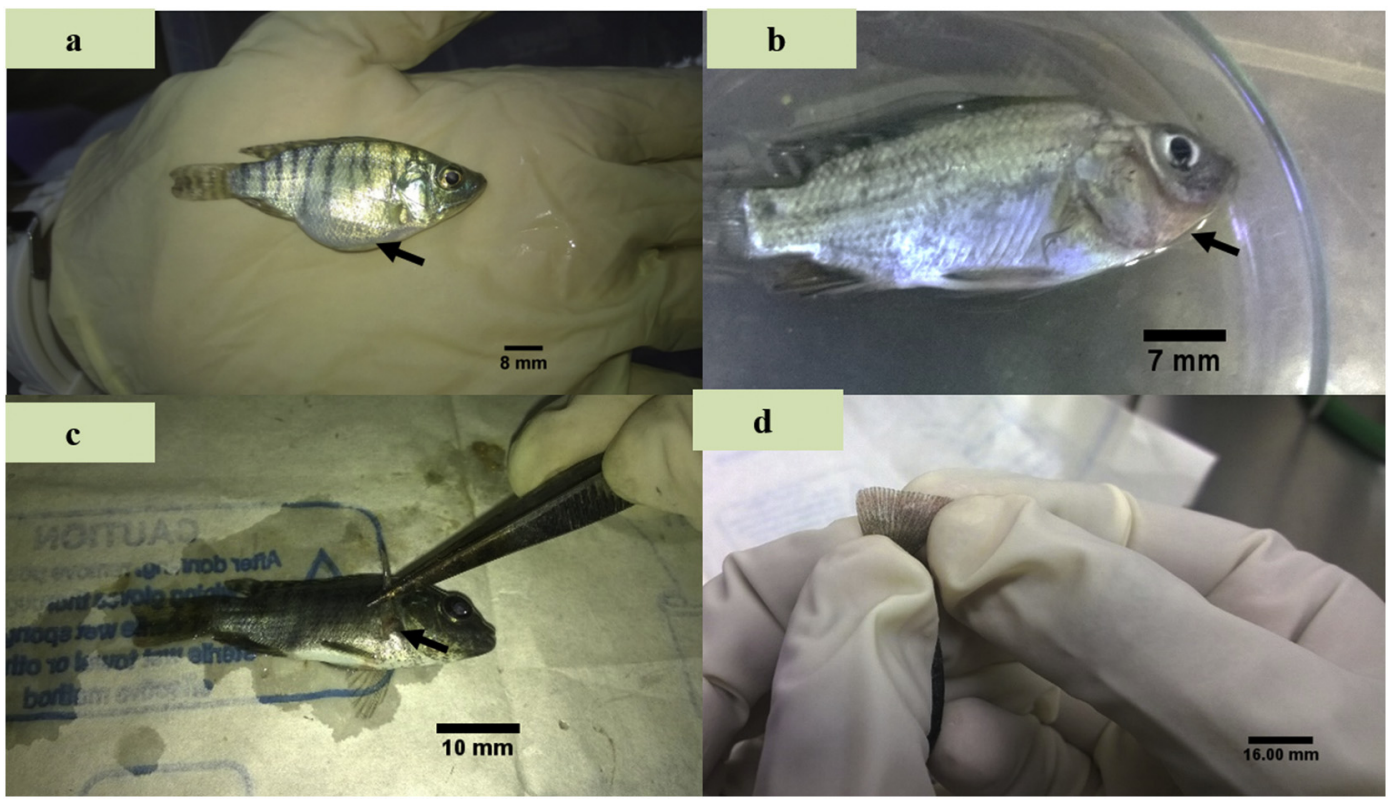

Fig. 5. Macroscopic lesions observed during experimental challenge. Fig. 5a Ascites; Fig. 5b: Petechiae on skin; Fig. 5c: Hemorrhagic spot at base of pelvic fin; Fig. 5d: Hemorrhages on caudal fin. 
$\mathbf{a}$

\section{Immersion challenge}

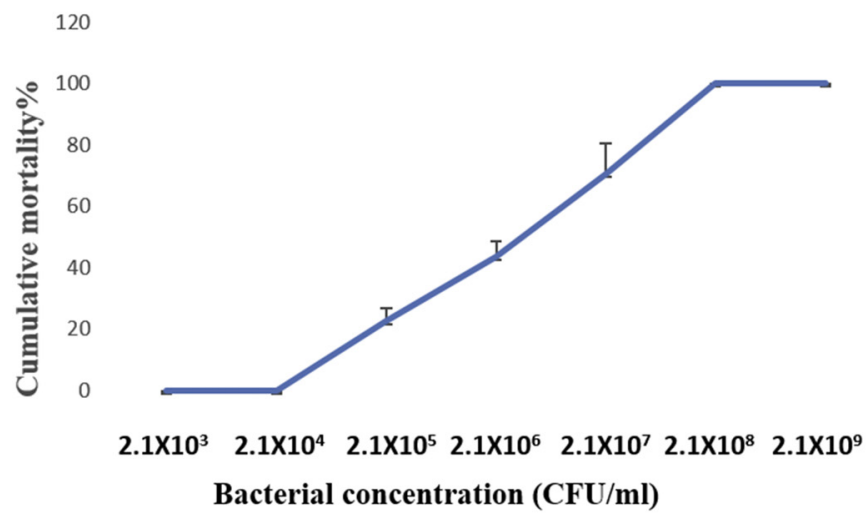

b

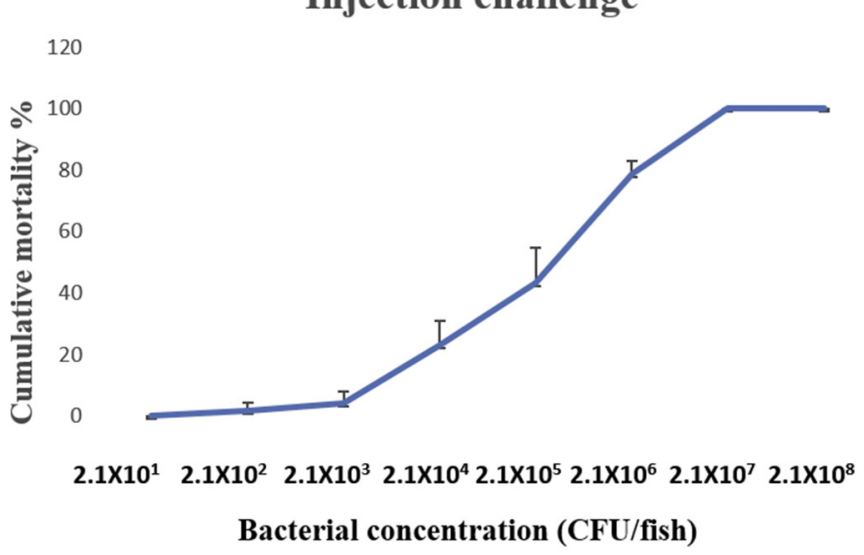

Fig. 6. Cumulative mortality \% (CMR) of tilapia juveniles during experimental challenge at different doses of $V$. vulnificus. Fig. 6a CMR\% after immersion challenge; Fig. 6b: CMR \% after injection challenge.

Error bars represent standard error.

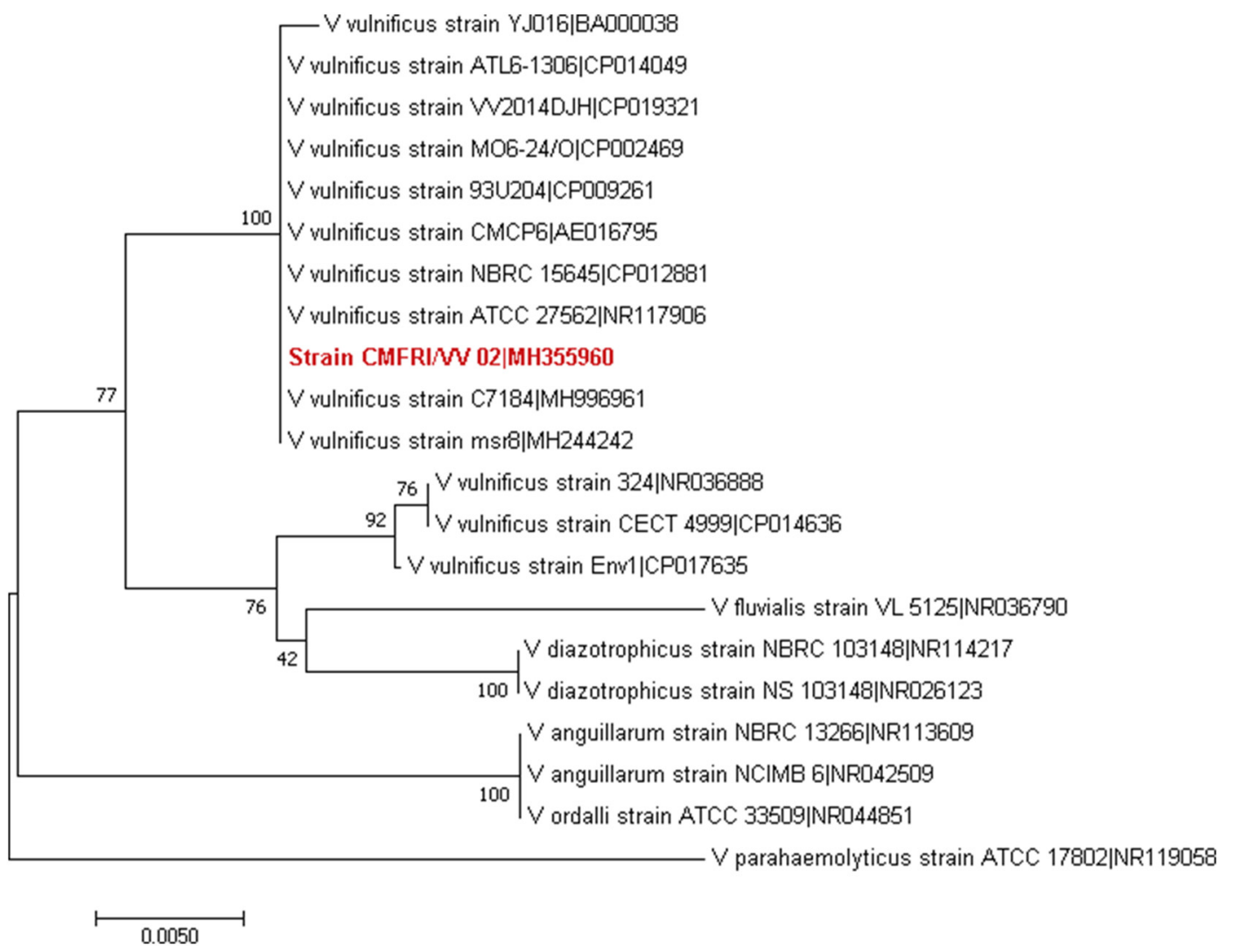

Fig. 7. Neighbor-joining tree of V. vulnificus CMFRI/VV-02 strain with other closely related Vibrio sp. based on $16 S$ rRNA gene sequence. Names of each bacteria including strain ID are followed by corresponding GenBank accession numbers.

salinity of $0-3 \%$ and $\mathrm{pH}$ of $6-10$.

\subsection{Bacterial survival in serum}

CMFRI/VV-02 strain could survive and multiply in serum samples of healthy tilapia fish. The bacterial survival at different temperature was given in Fig. 8. The bacterial survival ratio was higher at the end of the incubation period compared to control in all the temperatures which indicated that serum has not bacteriostatic or bactericidal activity against CMFRI/VV-02 strain. One-way ANOVA showed that there was a statistically significant difference in serum survival ratio between different temperatures $(p \leq .05)$. A Tukey post hoc test revealed serum survival was statistically significantly higher at $31{ }^{\circ} \mathrm{C}$ compared to $25^{\circ} \mathrm{C}$ and $28^{\circ} \mathrm{C}(\mathrm{p} \leq .05)$. There was no statistically significant difference between the survival at $25^{\circ} \mathrm{C}$ and $28^{\circ} \mathrm{C}(p=.646)$.

\subsection{0. vvhA gene sequence analysis}

$v v h A$ sequence analysis was followed to identify the genetic group of CMFRI/VV-02. The gene sequence of the strain (GenBank accession number MH357338) showed $100 \%$ identity to $V$. vulnificus group I (L180 strain) using NCBI-BLAST search. It was 99\% identical to that of 


\section{Serum survival test}

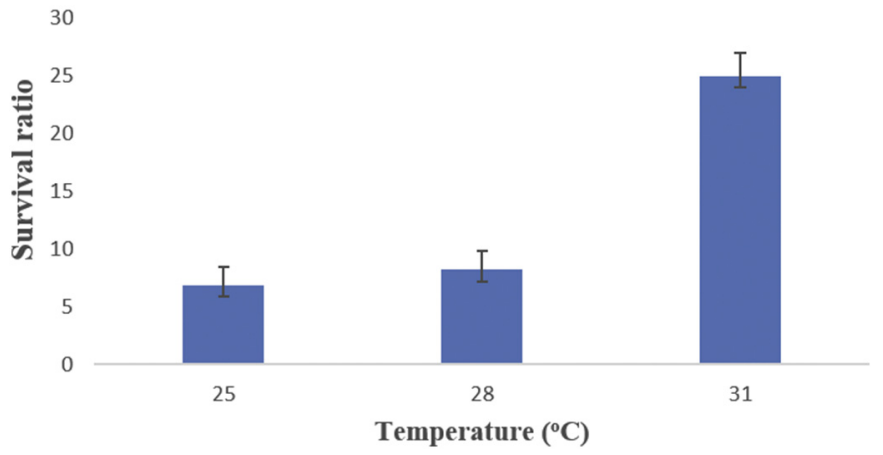

Fig. 8. Survival ratio of CMFRI/VV-02 strain after $4 \mathrm{~h}$ of incubation within naive tilapia serum compared to within PBS as control.

Error bars represent the standard error.

Tilapia strain from Taiwan (strain 93U204 with GenBank accession number CP009262.1). CMFRI/VV-02 strain demonstrated 95\% identity with CDC B3547 (human strain) (GenBank accession number AB124803.1) and CECT4999 (eel strain) (GenBank accession number CP014637), both of which belonged to Group II. Comparative phylogenetic tree analysis of CMFRI/VV-02 strain and other $V$. vulnificus strains using $v v h A$ sequences was portrayed in Fig. 9. There were clearly two clades in which CMFRI/VV02 clustered along with group I which also contained Taiwan tilapia strain 93 U204. The strains belonging to group 2 (eel pathogenic strains) formed a different clade. The branching of both clades I and II was exceptionally strong, as indicated by the high bootstrap value of $100 \%$.

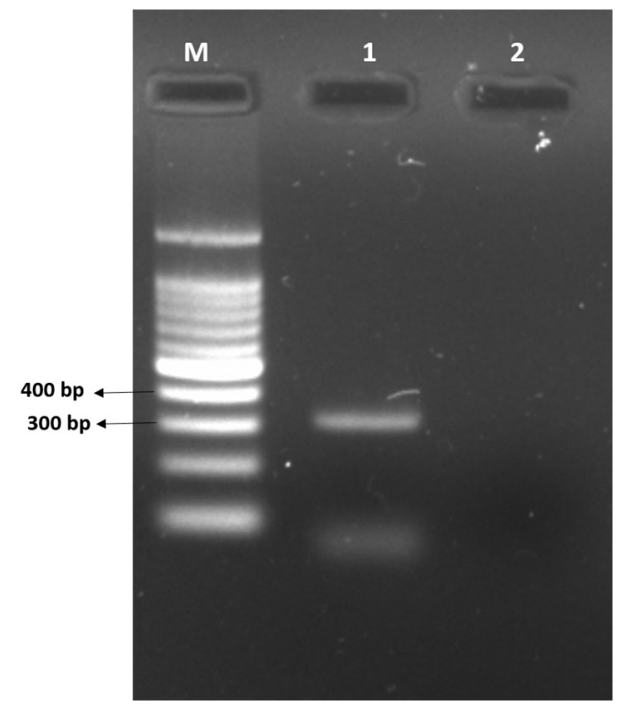

Fig. 10. PCR amplification of pilF gene fragment specific to $V$. vulnificus strains potentially dangerous for humans.

Lane M GeneRuler ${ }^{\mathrm{TM}} 1 \mathrm{~kb}$ DNA Ladder, Lane 1: Specific amplification product (338 bp); Lane 2: Negative control.

\subsection{1. pilF polymorphism-based PCR}

On PCR amplification of pilF gene fragment, an expected amplicon of $\sim 338$ bp was obtained (Fig. 10).

\subsection{Antibiotic susceptibility test}

In the antibiotic sensitivity test, the isolate was tested for its susceptibility to 23 antibiotics belonging to 9 different classes. CMFRI/

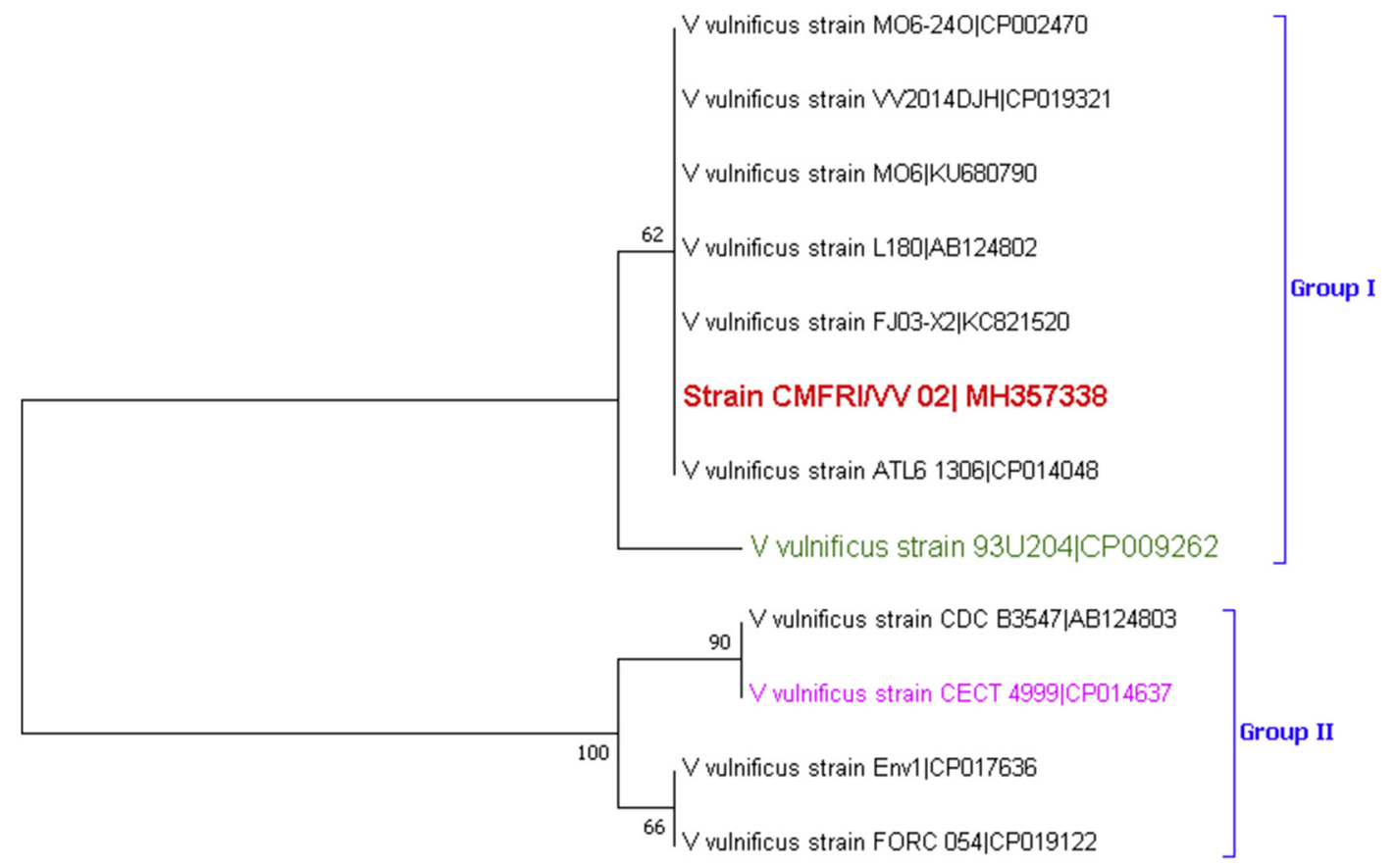

\subsection{0}

Fig. 9. Comparative phylogenetic tree analysis of CMFRI/VV-02 strain and other $V$. vulnificus strains using $v v h A$ sequence.

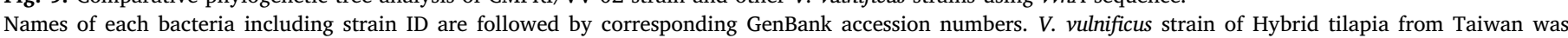

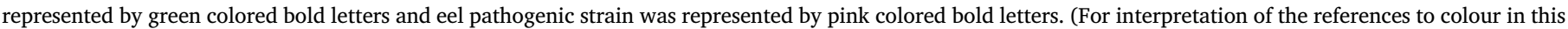
figure legend, the reader is referred to the web version of this article.) 
Table 1

Antibiotic susceptibility test- results.

\begin{tabular}{|c|c|c|c|c|}
\hline Sl No & $\begin{array}{l}\text { Class of } \\
\text { antimicrobials }\end{array}$ & Antibiotics & $\begin{array}{l}\text { Code (Number } \\
\text { indicates } \\
\text { concentration } \\
\text { in } \mu \text { g per disc) }\end{array}$ & $\begin{array}{l}\text { Result of } \\
\text { antibiogram } \\
\text { (R- Resistant; I- } \\
\text { Intermediate; } \\
\text { S-Sensitive) }\end{array}$ \\
\hline
\end{tabular}

\begin{tabular}{|c|c|c|c|c|}
\hline 1 & Penicillins & Ampicillin & $\mathrm{AMP}^{25}$ & $S$ \\
\hline 2 & & Piperacillin & $\mathrm{PI}^{100}$ & $S$ \\
\hline 3 & Cephalosporins & Cefoxitin & $\mathrm{CK}^{30}$ & $\mathrm{R}$ \\
\hline 4 & & Cefuroxime & $\mathrm{CXM}^{30}$ & I \\
\hline 5 & & Cefoperazone & $\mathrm{CPZ}^{75}$ & S \\
\hline 6 & Carbapenems & Meropenem & $\mathrm{MRP}^{10}$ & $S$ \\
\hline 7 & & Ertapenem & $\mathrm{ETP}^{10}$ & S \\
\hline 8 & & Imipenem & $\mathrm{IPM}^{10}$ & S \\
\hline 9 & Aminoglycosides & Kanamycin & $\mathrm{K}^{30}$ & S \\
\hline 10 & & Gentamicin & GEN $^{10}$ & $S$ \\
\hline 11 & & Streptomycin & $S^{10}$ & S \\
\hline 12 & & Amikacin & $\mathrm{AK}^{30}$ & S \\
\hline 13 & Quinolones & Levofloxacin & $\mathrm{LE}^{5}$ & S \\
\hline 14 & & Ciprofloxacin & $\mathrm{CF}^{10}$ & S \\
\hline 15 & & Lomefloxacin & $\mathrm{LOM}^{10}$ & S \\
\hline 16 & & Norfloxacin & $\mathrm{NX}^{10}$ & S \\
\hline 17 & & Ofloxacin & $\mathrm{OF}^{5}$ & S \\
\hline 18 & & Nalidixic acid & $\mathrm{NA}^{30}$ & $S$ \\
\hline 19 & Tetracyclines & Tetracycline & $\mathrm{TE}^{30}$ & S \\
\hline 20 & & Doxycycline & $\mathrm{DO}^{30}$ & S \\
\hline 21 & Polypeptides & Colistin & $\mathrm{CL}^{10}$ & $\mathrm{R}$ \\
\hline 22 & Sulphonamides & $\begin{array}{l}\text { Co-Trimoxazole } \\
\text { (Sulpha/ } \\
\text { Trimethoprim) }\end{array}$ & $\mathrm{COT}^{23.75 / 1.25}$ & S \\
\hline 23 & Others & Chloramphenicol & $C^{30}$ & $S$ \\
\hline
\end{tabular}

VV02 strain was resistant or intermediately resistant only to 3 antibiotics namely, Cefoxitin (CK30), Colistin (CL10) and Cefuroxime (CXM30) (Table 1). MAR index of the strain was 0.13.

\section{Discussion}

V. vulnificus, a multi-host pathogen is a common worldwide inhabitant of estuarine and marine ecosystems. It is commonly associated with zooplankton, crabs, and various filter feeders such as oysters and mussels. Simultaneously, $V$. vulnificus is a highly invasive pathogen of fish and humans. The organism is capable of causing rapidly fatal infections in humans following ingestion or wound contamination (Linkous and Oliver, 1999). Among fish, the pathogen is reported to cause substantial economic losses to eel aquaculture industry of Asia and Europe (Amaro et al., 1992). Simultaneously, V. vulnificus causes large epidemics of mortality in many other species of fish and the infected fish shows severe hemorrhagic body lesions (Li et al., 2006). Prevalence studies of $V$ vulnificus in India demonstrated its presence in the waters and wild caught fish and shellfish (Thampuran and Surendran, 1998; Parvathi et al., 2004; Sangeetha et al., 2017). However, pathological significance of $V$. vulnificus in fish cultured in Indian cage waters is not known till date.

Genetically Improved Farmed Tilapia (Oreochromis niloticus L.) are reported as the excellent candidates for aquaculture in offshore cage farms due to their ability to tolerate a wide range of water salinity (ElSayed, 2006). Presently, most of the farming of tilapia in India is based on fresh water. Recently, there is an increasing trend for the culture of fish in brackish water cages (Imelda et al., 2014). Nevertheless, no data are available on the diseases of fish cultured in brackish or marine waters of India. The first report of $V$. vulnificus infection among fish raised in a brackish water cage farm of India along with the detailed characterization of pathogen was documented through the present paper.

Outbreak of skin ulcers with mortality was recorded among tilapia sub-adults in a brackish water floating cage farm off Kochi, Kerala, India during January 2018. Total cumulative mortality was approx.
$20 \%$ and morbidity rate was $80 \%$. Affected fish showed dark discoloration of skin, surfacing, anorexia, corneal opacity, erratic swimming behavior, hemorrhagic lesions and ulcers. All fish showed typical septicemic changes during necropsy. The consistent histological lesion seen in all organs was hemorrhagic in nature, with the most prominent changes in liver. Water quality parameters were within optimal ranges for aquaculture during the outbreak. Bacterial isolation attempts from various internal organs (blood, kidney, liver and spleen) of different diseased fish indicated a common bacterial etiology in the stock. Based on conventional microbiological methods the infective bacteria were tentatively identified as $V$. vulnificus. As phenotypic plasticity of $V$. vulnificus necessitate molecular validation (Harwood et al., 2004), the bacterial identity was further confirmed by PCR using species specific primers (Kaysner and DePaola, 2004). Further, PCR targeting V. vulnificus virulent marker specific for fish-virulent strains was positive in the isolates (Sanjuan and Amaro, 2007). The mortality rate, clinical signs, macroscopic and microscopic lesions were compatible with other reports of V. vulnificus infections in European eels (Anguilla anguilla) (Biosca et al., 1991), Trachinotus ovatus (Li et al., 2006), Nile tilapia (O. niloticus) (Chen et al., 2006; Fouz et al., 2002; Sakata and Hattori, 1988) and Epinephyelus sp. (Liu et al., 1994).

Since all the strains isolated from various internal organs of different diseased fish indicated a common etiology, further pathogenicity studies were carried out using a representative strain (CMFRI/VV-02). Challenge experiments showed that $\mathrm{LD}_{50}$ value was $2.1 \times 10^{5.13} \mathrm{CFU} /$ fish and $2.1 \times 10^{6.123} \mathrm{CFU} / \mathrm{mL}$ in injection and immersion challenge respectively. There was $100 \%$ mortality following challenge with $\geq 2.1 \times 10^{7} \mathrm{CFU} /$ fish and $\geq 2.1 \times 10^{8} \mathrm{CFU} / \mathrm{mL}$ by injection and immersion route respectively. We propose that CMFRI/VV-02 can behave as a major pathogen for tilapia fish due to following three reasons. Primarily, after intramuscular challenge the strain showed $\mathrm{LD}_{50}$ of $2.1 \times 10^{5.13} \mathrm{CFU} /$ fish. Secondly, this strain was virulent even by immersion challenge; while other known tilapia pathogens like Streptococcus sp., were incapable to infect fish unless skin was scarified prior to challenge (Chang and Plumb, 1996; Fouz et al., 2002). Thirdly, the isolate efficaciously multiplied in healthy fish serum compared to control. This resistance to fish serum is essential for spreading of bacteria to main body organs (Amaro et al., 1997). Thus the results correlated with isolation of bacteria from various organs (blood, brain, liver, spleen and kidney) in both natural outbreak and challenge tests. Another noteworthy observation was there was a statistically significant difference in serum survival ratio between different temperatures $(p \leq .05)$. A Tukey post hoc test revealed serum survival was significantly higher at $31^{\circ} \mathrm{C}$ compared to $25^{\circ} \mathrm{C}$ and $28^{\circ} \mathrm{C}(\mathrm{p} \leq .05)$. In parallel to our observation, alteration in human serum survivability of $V$. vulnificus in response to fluctuation in temperature was observed Williams et al. (2014). This might explain the observation of Amaro et al. (1995) that increase in infective capacity of $V$. vulnificus at higher temperature.

As the prevalence of $V$. vulnificus was already demonstrated in Indian waters (Thampuran and Surendran, 1998; Parvathy et al., 2004), sea water and fouling of cage nets might be sources of infection in the present case. $V$. vulnificus outbreak in fish was found to be associated with moderate shifts in water salinity and increased in water temperature (Li et al., 2006). While the precipitating cause of disease outbreak during the present investigation is still unknown, moderate fluctuation in salinity along with persistent high water temperature of $31^{\circ} \mathrm{C}$ and high stocking density might have caused stress and disease in present case also. One interesting observation in the outbreak was; although it was a mixed cage farm with Pearl spots (Etroplus suratensis) and mangrove red snappers (Lutjanus argentimaculatus), only tilapia fish showed the clinical signs of infection and mortality. V. vulnificus infection associated with high stocking density stress was already reported in tilapia (Plumb, 1999). In accordance with the present observation, $V$. vulnificus infections were more reported in tilapia among different fish, next to eels. Species like Striped bass (Morone saxatilis), 
turbot (Scophthalmus maximus), sea bream (Sparus aurata) and trout (Oncorhynchus mykiss), are reported to be less susceptible or resistant to $V$. vulnificus than tilapia (Biosca and Amaro, 1996). Therefore, the exact reason for increased susceptibility of tilapia to V. vulnificus has to be thoroughly targeted in future studies.

To ascertain the zoonotic potential of the etiology, genetic typing based on $v$ whA gene (Senoh et al., 2005) and amplification of a variable region located within pilF gene which is associated with potential human pathogenicity (Roig et al., 2010) was further performed. Results demonstrated that CMFRI/VV-02 belonged to $v$ hA genetic type 1, for which human clinical strains are associated (Senoh et al., 2005). Additionally, pilF polymorphism-based PCR showed that CMFRI/VV-02 strain may pose potential danger for humans. Therefore, we postulated that $V$. vulnificus infected tilapia can pose a public health risk. The hypothesis is further supported by the case reports of $V$. vulnificus infections including septicaemia in humans after handling tilapia fish species (Chan et al., 1999; Vinh et al., 2006; Zaidenstein et al., 2008)

To pave the way for further insights on the virulence nature, presence of various virulence features was screened. The presumed virulence factors of $V$. vulnificus primarily comprise iron acquisition systems, hemolysin, protease, capsule as well as polar and lateral flagella (Natividad-Bonifacio et al., 2013). The strain showed positive results in all these five factors except protease. In agreement with this observation, Sakata and Hattori (1988) and Shao and Hor (2000) had suggested that extracellular protease is not primary virulent factor in $V$. vulnificus for tilapia and mice respectively. The observed $\beta$ haemolytic property was correlated with $v v h A$ detection, encoding a haemolysin with cytolysin activity. The tested strain was positive for siderophore production, by which the pathogen acquires iron during infection (Kim et al., 2008). Presence of polar and lateral flagella (swimming and swarming movements) in the strain will help in the colonization during pathogenesis (Natividad-Bonifacio et al., 2013). Capsule will help in resisting the action of complements and act as a triggering factor for septicaemia and lethality in V. vulnificus infection (Shapiro et al., 1998).

Antimicrobial susceptibility tests showed that CMFRI/VV-02 was resistant to only three antibiotics namely, Cefoxitin, Cefuroxime and Colistin (out of 23 tested antibiotics) with MAR index of 0.13. The MAR index of the strain $(\leq 0.2)$ indicated that the strain has originated from a low risk source of contamination with antibiotics (Paul et al., 1997). Even though the strain was found to be susceptible to many tested antibiotics, use of antibiotics against $V$. vulnificus is not recommended. As the continuous use of antibiotics could reduce their efficacy and promote the development of antibiotic resistant bacteria (Monteiro et al., 2016), prophylactic management through development of an efficient vaccine or antagonistic feed represents the best strategy for controlling the diseases in aquaculture/mariculture facilities.

\section{Conclusions}

The present paper described the pathological features of natural outbreak by $V$. vulnificus within a cage farm of tilapia fish in Indian water for the first time. The rapid growth rate of tilapia coupled with high stocking density and increased water temperature could be the precipitating causes for the outbreak. Results of challenge tests confirmed that $V$. vulnificus could act as a primary pathogen for tilapia reared in brackish water. pilF polymorphism-based PCR and $v v h A$ gene sequence of CMFRI/VV-02 strain indicated that $V$. vulnificus infected tilapia may pose a public health risk; and fish farmers should take appropriate preventive measures during vibriosis episodes. Management measures, including avoidance of overcrowding, prompt removal of moribund fish, altering the interior net of the sea cage and its location and providing shade, while the water temperature rises can be adopted. At the same time, further study on prevalence and population structure of $V$. vulnificus in cage farms and development of proper prophylactic management including an efficient vaccine or antagonistic cum immuno-stimulant feed are recommended in future research.

\section{Acknowledgements}

The authors are grateful to the Head, Marine Biotechnology Division and the Director, ICAR-Central Marine Fisheries Research Institute, Kochi for providing necessary facilities to carry out the present investigation. This work was supported by ICAR-CMFRI institute funded project "Health Management in selected finfish and shellfish \& bioprospecting from marine resources". APV acknowledges CSIR -UGC for the research fellowship. SG acknowledges ICAR funded "All India network project on fish health" for Senior Research Fellowship.

\section{Conflicts of interest}

None.

\section{References}

Amaro, C., Biosca, E.H., Esteve, C., Fouz, B., Toranzo, A.E., 1992. Comparative study of phenotypic and virulence properties in Vibrio vulnificus biotypes 1 and 2 obtained from a European eel farm experiencing mortalities. Dis. Aquat. Org. 13, 29-35.

Amaro, C., Biosca, E.G., Fouz, B., Alcaide, E., Esteve, C., 1995. Evidence that water transmits Vibrio vulnificus biotype 2 infections to eels. Appl. Environ. Microbiol. 61, 1133-1137.

Amaro, C., Fouz, B., Biosca, E.G., Marco-Noales, E., Collado, R., 1997. The lipopolysaccharide $\mathrm{O}$-side chain of Vibrio vulnificus $\mathrm{E}$ is a virulence determinant for eels. Infect. Immun. 65, 2475-2479.

Bergey, D., Whitman, W., Good-fellow, M., Kaampfer, P., Busse, H., 2012. Bergey's Manual of Systematic Bacteriology. Springer, New York.

Bigarre, L., Cabon, J., Baud, M., Heimann, M., Body, A., Lieffrig, F., Castric, J., 2009. Outbreak of betanodavirus infection in tilapia, Oreochromis niloticus (L.), in fresh water. J. Fish Dis. 32, 667-673.

Biosca, E.G., Amaro, C., 1996. Toxic and enzymatic activities of Vibrio vulnificus biotype 2 with respect to host specificity. Appl. Environ. Microbiol. 62, 2331-2337.

Biosca, E.G., Amaro, C., Esteve, C., Alcaide, E., Garay, E., 1991. First record of Vibrio vulnificus biotype 2 from diseased European eel, Anguilla anguilla L. J. Fish Dis. 14, 103-109.

Chan, W.L., Chan, C.H.S., Chan, T.Y.K., 1999. Vibrio vulnificus septicaemia and necrotizing fasciitis after a prick from the dorsal fin of a tilapia. Trans. R. Soc. Trop. Med. Hyg. 93, 174.

Chang, P.H., Plumb, J.A., 1996. Effects of salinity on Streptococcus infection of Nile tilapia, Oreochromis niloticus. J. Appl. Aquac. 6, 39-45.

Chatterjee, S., Haldar, S., 2012. Vibrio related diseases in aquaculture and development of rapid and accurate identification methods. J. Marine Sci. Res. Dev. S1, 002.

Chen, C.Y., Chao, C.B., Bowser, P.R., 2006. Infection of tilapia Oreochromis sp. by Vibrio vulnificus in freshwater and low-salinity environments. J. World Aquacult. Soc. 37, 82-88.

Clinical and Laboratory Standard Institute (CLSI), 2018. Performance Standards of Antimicrobial Disc Susceptibility Tests. vol. 38 (1) (Jan 2018).

De Tolla, L.J., Srinivas, S., Whitaker, B.R., Andrews, C., Hecker, B., Kane, A.S., Reimschuessel, R., 1995. Guidelines for the care and use of fish in research. ILAR J. 37, 159-173.

El-Sayed, A.F.M., 2006. Tilapia Culture. CABI, Cambridge, MA, USA.

Eyngor, M., Zamostiano, R., Tsofack, J.E.K., Berkowitz, A., Bercovier, H., Tinman, S., Lev, M., Hurvitz, A., Galeotti, M., Bacharach, E., Eldar, A., 2014. Identification of novel RNA virus lethal to tilapia. J. Clin. Microbiol. 52, 4137-4146.

FAO (Food and Agriculture Organization), 2018. The State of World Fisheries and Aquaculture 2018 - Meeting the Sustainable Development Goals; Rome. http://www. fao.org/3/i9540en/I9540EN.pdf.

Fouz, B., Amaro, C., 2003. Isolation of a new serovar of Vibrio vulnificus pathogenic for eels cultured in freshwater farms. Aquaculture 217, 677-682.

Fouz, B., Alcaide, E., Barrera, R., Amaro, C., 2002. Susceptibility of Nile tilapia (Oreochromis niloticus) to vibriosis due to Vibrio vulnificus biotype 2 (serovar E). Aquaculture 212, 21-30.

Harwood, V.J., Gandhi, J.P., Wright, A.C., 2004. Methods for isolation and confirmation of Vibrio vulnificus from oysters and environmental sources: a review. J. Microbiol. Methods 59, 301-316.

Imelda, J., Ignatius, B., Venugopal, K.M., 2014. Cage culture of GIFT tilapia: A farming option during monsoon season in traditional shrimp ponds. In: Central Marine Fisheries Research Institute, Kochi. CMFRI Pamphlet No. 23/2014, . http://eprints. cmfri.org.in/10133/1/GIFT_Tilapia.pdf (accessed on 03 September 2018).

Kaysner, C.A., DePaola, A., 2004. Vibrio. Bacteriological Analytical Manual Online. U.S. Food and Drug Administration, Washington, DC.

Kim, I.H., Shim, J.I., Lee, K.E., Hwang, W., Kim, I.J., Choi, S.H., Kim, K.S., 2008. Nonribosomal peptide synthetase is responsible for the biosynthesis of siderophore in Vibrio vulnificus MO6-24/O. J. Microbiol. Biotechnol. 18, 35-42.

Krumperman, P.H., 1983. Multiple antibiotic resistance indexing of Escherichia coli to identify high-risk sources of faecal contamination of foods. Appl. Environ. Microbiol. 46, 165-170.

Kumar, S., Stecher, G., Tamura, K., 2016. MEGA7: molecular evolutionary genetics analysis version 7.0 for bigger datasets. Mol. Biol. Evol. 33, 1870-1874. 
Lavilla-Pitogo, C.R., Albright, L.J., Paner, M.G., Sunaz, N.A., 1992. Studies on the sources of luminescent Vibrio harveyi in Penaeus monodon hatcheries. In: Shariff, M., Subasinghe, R.P., Arthur, J.R. (Eds.), Diseases in Asian Aquaculture I. Fish Health Section Asian Fisheries Society, Manila, Philippines, pp. 157-164.

Levin, R.E., 2005. Vibrio vulnificus, a notably lethal human pathogen derived from seafood: a review of its pathogenicity, subspecies characterization, and molecular methods of detection. Food Biotechnol. 19, 69-94.

Li, G., Zhao, D., Huang, L., Sun, J., Gao, D., Wang, H., Tan, Y., Liang, L., 2006. Identification and phylogenetic analysis of Vibrio vulnificus isolated from diseased Trachinotus ovatus in cage mariculture. Aquaculture 261, 17-25.

Linkous, D.A., Oliver, J.D., 1999. Pathogenesis of Vibrio vulnificus. FEMS Microbiol. Lett. $174,207-214$.

Liu, X., Zou, X., Xiaoyan, M., Jiabing, L., Zhenteng, Y., Rongsheng, W., Tejian, W., Zhu, Sh., 1994. A study on the pathogen of vibrisis isolated from diseased Epinephelus sp. in cage mariculture. Trop. Oceanol. 13, 81-86.

McGeachin, R.B., Wicklund, R.I., Olla, B.L., Winton, J.R., 1987. Growth of Tilapia aurea in seawater cages. J. World Aquacult. Soc. 18, 31-34.

Monteiro, S.H., Garcia, F., Gozi, K.S., Romera, D.M., Francisco, J.G., Moura-Andrade, G.C., Tornisielo, V.L., 2016. Relationship between antibiotic residues and occurrence of resistant bacteria in Nile tilapia (Oreochromis niloticus) cultured in cage-farm. J. Environ. Sci. Health B 51, 817-823.

Moreno, G.M.L., Landgraf, M., 1998. Virulence factors and pathogenicity of Vibrio vulnificus strains isolated from seafood. J. Appl. Microbiol. 84, 747-751.

Mugamire, M., Borel, P., Mwanja, W., Tutaisire, J., Balirwa, J., Wadanya, J., Aliyo, A., Kivunike, G., 2013. National Investment Policy for Aquaculture Parks in Uganda. ICBE Policy Brief. https://www.africaportal.org/publications/national-investmentpolicy-for-aquaculture-parks-in-uganda/ (accessed on 03 September 2018).

Mukherjee, S.C., 2002. Fish diseases in India, their causes and control measures - Winter school on recent advances in diagnosis and management of diseases in mariculture, 7th to 27th November 2002. In: Course Manual. Central Marine Fisheries Research Institute, Kochi. http://eprints.cmfri.org.in/5453/1/27._Muk.pdf (accessed on 03 September 2018).

Muroga, K., Jo, Y., Nishibuchi, M., 1976. Pathogenic Vibrio isolated from cultured eels. Its characteristics and taxonomic status. Fish Pathol. 11, 141-145.

Nair, A.V., Vijayan, K.K., Chakraborty, K., 2012. Diversity and characterization of antagonistic bacteria from tropical estuarine habitats of Cochin, India for fish health management. World J. Microbiol. Biotechnol. 28, 2581-2592.

Natividad-Bonifacio, I., Fernandez, F.J., Quinones-Ramırez, E.I., Curiel-Quesada, E., Vazquez-Salinas, C., 2013. Presence of virulence markers in environmental Vibrio vulnificus strains. J. Appl. Microbiol. 114, 1539-1546.

Parvathi, A., Kumar, H.S., Karunasagar, I., 2004. Detection and enumeration of Vibrio vulnificus in oysters from two estuaries along the southwest coast of India, using molecular methods. Appl. Environ. Microbiol. 70, 6909-6913.

Paul, S., Bezbaruah, R.L., Roy, M.K., Ghosh, A.C., 1997. Multiple antibiotic resistance (MAR) index and its reversion in Pseudomonas aeruginosa. Lett. Appl. Microbiol. 24, 169-171.

Plumb, J.A., 1999. Tilapia bacterial diseases. In: Plumb, J.A. (Ed.), Health Maintenance and Principal Microbial Diseases Cultured Fishes. Iowa State Univ. Press, Ames, pp. 297-305.

Pretto-Giordano, L.G., Muller, E.E., Klesius, P., da Silva, V.G., 2010. Efficacy of an experimentally inactivated Streptococcus agalactiae vaccine in Nile tilapia (Oreochromis niloticus) reared in Brazil. Aquac. Res. 41, 1539-1544.

Reed, M.J., Muench, H., 1938. A simple method for estimating fifty percent end point. Am. J. Hyg. 27, 493S-497S.

Roig, F.J., Sanjuan, E., Llorens, A., Amaro, C., 2010. pilf polymorphism-based PCR to distinguish Vibrio vulnificus strains potentially dangerous to public health. Appl. Environ. Microbiol. 76, 1328-1333.

Rutaisire, J., Charo-Karisa, H., Shoko, A.P., Nyandat, B., 2009. Aquaculture for increased fish production in East Africa. Afr. J. Trop. Hydrobiol. Fish. 12, 74-77.

Sakata, T., Hattori, M., 1988. Characteristics of Vibrio vulnificus isolated from diseased tilapia. Fish Pathol. 23, 33-40.

Samuelsson, O.B., Nerland, A.H., Jorgensen, T., Schroder, M.B., Svasand, I.T., Berghm, Q., 2006. Viral and bacterial diseases of Atlantic cod, Gadus morhua L. their prophylaxis and treatment: a review. Dis. Aquat. Org. 71, 239-254.

Sandlund, N., Rodseth, O.M., Knappskong, D.H., Fiksdal, I.U., Berg, O., 2010. Comparative susceptibility of turbot, halibut and cod yolk-sac larvae to challenge with Vibrio spp. Dis. Aquat. Org. 89, 29-37.

Sangeetha, M.S., Shekar, M., Venugopal, M.N., 2017. Occurrence of clinical genotype Vibrio vulnificus in clam samples in Mangalore, Southwest coast of India. J. Food Sci. Technol. 54, 786-791.

Sanjuan, E., Amaro, C., 2007. Multiplex PCR assay for detection of Vibrio vulnificus biotype 2 and simultaneous discrimination of serovar E strains. Appl. Environ. Microbiol. 73 (6), 2029-2032.

Sarjito, R., Radjasa, O.K., Sabdono, A., Prayitno, S.B., Hutabarat, S., 2009. Phylogenetic diversity of the causative agents of vibriosis associated with groupers fish from Karimunjawa Islands, Indonesia. Curr. Res. Bacteriol. 2, 14-21.

Schwyn, B., Neilands, J.B., 1987. Universal chemical assay for the detection and determination of siderophores. Anal. Biochem. 160, 47-56.

Senoh, M., Miyoshi, S., Okamoto, K., Fouz, B., Amaro, C., Shinoda, S., 2005. The cytotoxin-hemolysin genes of human and eel pathogenic Vibrio vulnificus strains: comparison of nucleotide sequences and application to the genetic grouping. Microbiol. Immunol. 49, 513-519.

Shao, C.P., Hor, L.I., 2000. Metalloprotease is not essential for Vibrio vulnificus virulence in mice. Infect. Immun. 68, 3569-3573.

Shapiro, R.L., Altekruse, S., Hutwagner, L., Wilson, S., Ray, B., Thompson, S., Tauxe, R.V., Griffin, P.M., 1998. The role of Gulf Coast oysters harvested in warmer months in Vibrio vulnificus infections in the United States, 1988-1996. J. Infect. Dis. 178, 752-759.

Sharma, K.S.R., Rathore, G., Verma, D.K., Sadhu, N., Philipose, K.K., 2013. Vibrio alginolyticus infection in Asian seabass (Lates calcarifer, Bloch) reared in open sea floating cages in India. Aquac. Res. 44, 86-92.

Shoemaker, C.A., Lafrentz, B.R., Klesius, P.H., 2011. Vaccination of sex reversed hybrid tilapia (Oreochromis niloticus $\times$ O. aureus) with an inactivated Vibrio vulnificus vaccine. Biologicals 39, 424-429.

Stentiford, G.D., Neil, D.M., Peeler, E.J., Shields, J.D., Small, H.J., Flegel, T.W., Vlak, J.M., Jones, B., Morado, F., Moss, S., Lotz, J., Bartholomay, L., Behringer, D.C., Hauton, C., Lightner, D.V., 2012. Disease will limit future food supply from the global crustacean fishery and aquaculture sectors. J. Invertebr. Pathol. 110, 141-157.

Thampuran, N., Surendran, P.K., 1998. Occurrence and distribution of Vibrio vulnificus in tropical fish and shellfish from Cochin (India). Lett. Appl. Microbiol. 26, 110-112.

USFWS/AFS-FHS, 2004. Standard Procedures for Aquatic Animal Health Inspections. https://www.fws.gov/policy/aquatichandbook/Volume_1/Chapter_2.pdf.

Vinh, D.C., Mubareka, S., Fatoye, B., Plourde, P., Orr, P., 2006. Vibrio vulnificus septicemia after handling Tilapia species fish: a Canadian case report and review. Can. J. Infect. Dis. Med. Microbiol. 17, 129-132.

Watanabe, W., Ernst, D., Olla, B., Wicklund, R., 1989. Aquaculture of red tilapia Oreochromis sp. in marine environments. In: State of the art. Actes de colloques Ifremer, Tahiti, French Polynesia, 20 Feb - 4 Mar 1989, n9, chap. 46, pp. 487-498.

Williams, T.C., Ayrapetyan, M., Ryan, H., Oliver, J.D., 2014. Serum survival of Vibrio vulnificus: role of genotype, capsule, complement, clinical origin, and in-situ incubation. Pathogens 3, 822-832.

Wilson, K., 1987. Preparation of genomic DNA from bacteria. In: Ausubel, F.M., Brent, R. Kingston, R.E., Moore, D.D., Seidman, J.G., Smith, J.A. (Eds.), Current Protocols in Molecular Biology. Wiley, New York.

Zaidenstein, R., Sadik, C., Lerner, L., Valinsky, L., Kopelowitz, J., Yishai, R., Agmon, V., Parsons, M., Bopp, C., Weinberger, M., 2008. Clinical characteristics and molecular subtyping of Vibrio vulnificus illnesses. Israel. Emerg. Infect. Dis. 14, 1875-1882.

Zhou, Q., Li, K., Jun, X., Bo, L., 2009. Role and functions of beneficial microorganisms in sustainable aquaculture. Bioresour. Technol. 100, 3780-3786. 